\title{
コミュニカティブ・アプローチに関する日本人高 校英語教師の信条と実践
}

\section{Japanese High School Teachers' Beliefs and Practices Regarding Communicative Language Teaching}

\section{西野孝子(にしの たかこ) \\ Takako Nishino \\ 神田外語大学 \\ Kanda University of International Studies}

Borg (2003) defines "teacher cognition" as how teachers think, know, and believe. According to Borg, teacher cognition, classroom practices, learning experiences, teacher education, and contextual factors all relate to and influence each other. $\mathrm{He}$ also points out that researchers need to investigate the cognition of secondary school English teachers whose first language is not English, particularly those working with large classes of learners. Accordingly, in this study, I investigated how Japanese high school teachers perceive the use of Communicative Language Teaching (CLT) in their English classes.

Since 1989, the Japanese Ministry of Education, Culture, Sports, Science and Technology (MEXT) has attempted to promote higher achievement in English communicative skills among secondary school students by urging teachers to use CLT. This focus on CLT in Japan contrasts sharply with the traditional and arguably still dominant yakudoku method, which involves decontextualized grammatical instruction and word-by-word translation of written English into Japanese. To achieve this communicative innovation, MEXT institututed a 5-year Action Plan in which inten-

JALT Journal, Vol. 33, No. 2, November 2011 
sive teacher training programs for 60,000 secondary school English teachers and the introduction of a listening component in the Center Test (a nationwide college entrance exam) were important features.

To date, little research has been done on how high school teachers perceive and use CLT and how their cognition has been affected by its communicative orientation. To investigate teachers' cognitive and practical adjustment to this landmark innovation, I conducted a survey of Japanese high school teachers' cognition and practices regarding CLT. I posited three questions:

- What beliefs do Japanese high school teachers hold about CLT?

- How do they use CLT in their English classrooms?

- How do they perceive their teaching efficacy, their experiences in pre- and in-service training, their learning experiences, and contextual factors?

Data were obtained through a questionnaire, based on previous studies of teacher cognition. The questionnaire was sent to randomly selected Japanese high schools in the fall of 2006, and 139 teachers responded. The data were analyzed using descriptive statistics, $t$-tests, and a one-way analysis of variance (ANOVA).

As regards the first research question, the descriptive statistics showed that the respondents held positive beliefs about CLT. At the same time, they believed that rote memorization is important. In addition, more than half of the respondents said that they wanted to make their lessons more communicative, and the largest number answered that smaller class size should be maintained in order to use CLT effectively.

With respect to the second research question, the respondents did not frequently use communicative activities. There seemed to be a gap between their reported beliefs and practices.

Concerning the third research question, results indicated that (a) the respondents had less confidence in their ability to implement CLT than in their English skills and grammatical knowledge, (b) the respondents had fewer opportunities in pre-service training courses than in in-service training programs to receive practical training in CLT, (c) they perceived that the classroom conditions were not optimal for the use of CLT, (d) MEXT innovations had not strongly influenced their classroom practices, and (e) they had had few chances to experience communicative activities in English class when they themselves were in high school. It appears that these factors had a negative influence on the respondents' use of CLT.

In summary, the respondents held positive beliefs about CLT, but there was a gap between their reported beliefs and practices. In order to make Japanese high school English lessons more communicative, contextual factors and teacher training programs should be re-examined and context-appropriate communicative methodologies should be developed by teachers themselves.

文部科学省は、1980年年代後半から英語によるコミュニケーション能力を高めようと、 高校の授業でのコミュニカティブ・アプローチ（CLT）の採用を促してきた。また、2003 年から 5 年間にわたり「『英語が使える日本人』の育成のための行動計画」を実施し、そ 
の方針の具体的な実現を図った。本研究では、無作為抽出した高校に質問票を送付し、日 本人高校教師がCLTをどのように考え実践しているか、また、教師としての能力、教職課 程、教員研修、学習経験、教育環境などをどのようにとらえているかについて、2006年秋 に調査した。その結果、回答者139名の約60\%は、CLTの理念（「言葉は使うことで効果 的に習得」「コミュニケーション能力の育成が大切」「間違いは学習の一環」など）に賛 成（或いは強く賛成）しているが、コミュニケーション活動を普段の授業で使っている回 答者は全体の $30 \%$ に満たないことがわかった。結果を踏まえてどのような要因がCLTの実 践に影響しているかを考察する。

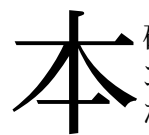

研究は、日本人高校英語教師が、コミュニカティブ・アプローチ(あるいは コミュニカティブ・ランゲージ・ティーチング、以下CLT)についてどのよう な信条をもち、どのように実践しているかを探るものである。Clark and Peterson (1986)による教師思考に関する研究以降、「教師の信条」が研究のひとつの カテゴリーとして注目されてきたが、その定義は様々である(笹島・ボーグ， 2009)。 本研究では教師の信条を、「教育や学習について、教師がそれまでの経験を通して 構築してきた考え方で、教師の意思決定と授業実践に影響を与えるもの」(Pajares, 1992参照) と定義する。

SL/FL教室における研究では、教師の信条が授業実践に強く影響すること、教師 の信念体系 (belief system)が複雑であることが報告されている(Burns, 1996; Pajares, 1992; Woods, 1996)。Burnsは、信念体系は教科、言語、学習者、教材などについての 信条が網の目のようになって構成されると述べている。したがって、信念体系の中で は相いれない信条が共存することもあり、どの信条を報告するかによって、教師の信 条と実践にずれが生ずることもあり得る。

教師の信条と実践とのずれが、教育環境の影響に起因する場合もある(Crookes, 1997; Fang, 1996; Schulz, 2001)。この場合の教育環境は、教室環境(生徒の英語力や 学習スタイル、クラスサイズなど)、学校環境 (シラバス、設備、教員研修、父母の要望 など)、および教育をとりまく社会環境(入試を含む教育政策、教師の労働条件、学習 指導要領など)を意味する。また、教師自身の過去の学習経験 (Holt-Reynolds, 1992) や教師としての経験 (Crookes \& Arakaki, 1999)、教師としての能力への自信 (Smylie, 1988)なども授業実践に影響を及ぼすことが報告されている。

以上のような教師の信条や考え方、授業実践、それらに影響を及ぼす様々な要 因を探る研究を、Borg (2003) は「教師認知研究」と定義した。「教師認知」とは、教 師の信条、知識、理論、態度、考え方などを包括して表す用語である。同著でBorg は、1980年代からの文献レビューに基づき、「教師認知研究のための概念枠組み」を 提案した。さらにBorg (2006) では言語教師認知に焦点をあて、この枠組みを部分的 に改訂して「言語教師認知の要素とプロセス」を呈示し、言語教師認知が学習経験、 教職専門研修(大学の教職課程や教員研修)、教育環境、授業実践1などと複雑に関 係し、影響し合いながら構築され、さらに再構築されることを示唆した (図 1 参照)。こ の枠組みは、教師の信条知識、実践、研修などに関する様々な研究を関連付けて解 釈するのに役立つだけでなく、過去の研究に欠けている点や今後の研究のテーマな どを際立たせる意味でも有効である。 


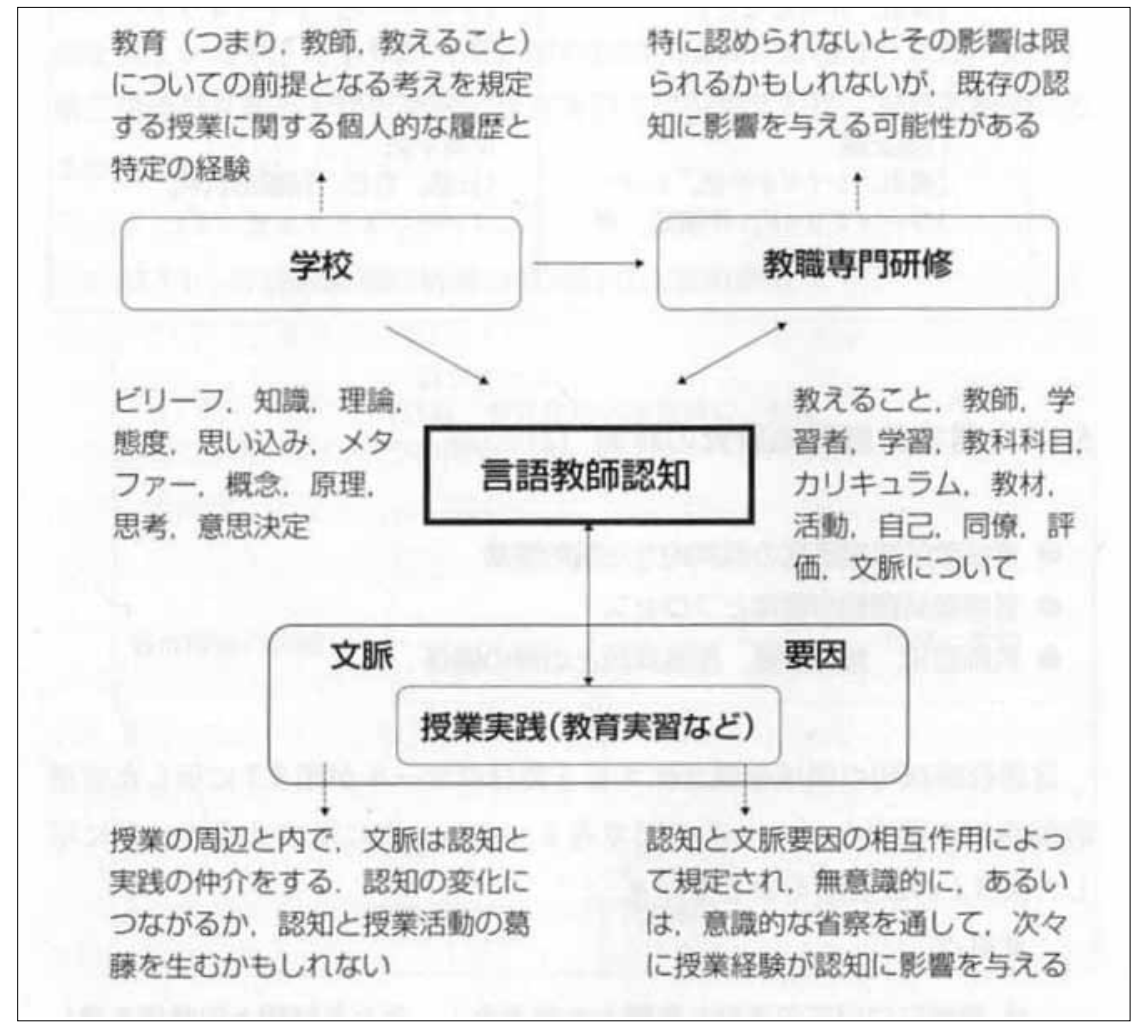

図1. 言語教師認知の要素とプロセス (Borg, 2006; 笹島・ボーグ, 2009)

言語教師認知研究についてBorg (2006) は、ある特定の分野や教え方に焦点をあ てる必要性があるとし、加えて言語教師認知研究は外国語を必修科目として教えて いる中学高校の教師についての研究に欠けると指摘した。

本研究は、Borg (2006) の概念枠組みに基づき、日本人高校英語教師の信条と授 業実践に焦点をあてた言語教師認知研究である。我が国でコミュニカティブな英語 の授業を目指す様々な改革(「背景」参照)が約20年を経た現在、英語教師がCLTを どうとらえているか、実際にCLTは使われているか、教師は自分の経験や教育環境を どう認識しているか、それが実践に影響しているのか、などを調べることにより、教育 現場の現状を知り、今後の展望を探ることは意義深い。本研究は、日本人高校英語 教師の信条、授業実践、学習経験、教職専門研修、教育環境などについて、CLTに 焦点を絞って調査するものである。 


\section{背景}

CLTは、コミュニケーション能力を伸ばすことを目的とし、言葉の4技能 (聞く、話 す、読む、書く) を伝達の手段として教えるアプローチ、と定義できる（Richards \& Rodgers, 2001）。CLTは具体的な教授法ではなく、言語教育の理念や実践の基礎と なる理論 (アプローチ) であるため、CLTに基づく教え方は様々であるが、その特徵 は、実際のコミュニケーションやタスグが学習を促し、意味のある言語使用が学習 を助けるという考え方にある (Richards \& Rodgers)。CLTはヨーロッパ及び北米で 1970年代に発展し、1990年頃からアジアの国々における英語教育改革に影響を与え てきたが (Nunan, 2003)、日本での状況はどうであろうか。

日本の学校教育が19世紀末に始まって以来、英語の授業では「訳読」が主に行わ れてきた。訳読による授業では、教科書の逐語訳と日本語による文法の説明が主で あり、英語を話したり聞いたりする活動はほとんどない。Gorsuch (1998)によれば、訳 読の実践には大学入試が影響しており、入試問題の多くは文法の知識や日本語訳を 尋ねるもので、受験指導のためには訳読の方がコミュニケーション活動よりも重要で あると考えられてきた。3

一方、国のカリキュラムとして1947年から発行されている、文部省 (2001年より文 部科学省)の定める学習指導要領では、訳読が推奨されたことは一度もなく、4技能 のバランス良い指導が提唱されてきた。しかし学習指導要領では「どう教えるか」とい うことにほとんど言及されていないことから、シンボル的なものとして扱われ、高等学 校ではあまり重要視されていないとGorsuch(2000b)が述べている。

1980年代から始まったグローバル化の中で日本の教育も国際化の様相を帯びてき た。文部科学省は1987年にJapan Exchange and Teaching Programを導入した。海外 から大学卒の若者を国際交流の一環として招き、主に英語の授業の教員助手 (ALT) として採用した。次いで1989年に学習指導要領を改訂し、外国語教育の目標のひと つに「コミュニケーションへの積極的な態度の育成」を加える(文部省，1989）。英語 科目にオーラル・コミュニケーションが導入されたのもこの改訂版 (1993年実施) であ る。1999年の改訂では外国語教育の目標に「実践的コミュニケーション能力を養う」こ とが示され、英語科目は英語I・II (総合英語)、オーラル・コミュニケーションI・II、リー ディング、ライティングの6コースになつた(文部省, 1999)。

さらに文部科学省は、2003年に5年間にわたる「『英語が使える日本人』の育成の ための行動計画」（以下行動計画）を発表し（文部科学省，2003）、2006年度から大 学入試センター試験にリスニングの問題が出題されることになった。また、文部科学 省は、都道府県教育委員会に委託して、6万人に及ぶ公立中学高校の英語科教員を 対象に「悉皆研修」を実現した。悉皆研修には大学教員、英語会話学校教員などが 講師として招かれ、英語教師の英語力の向上とコミュニカティブな授業の実現を目 標に、7〜10日間のワークショップやセミナーが催された。文部科学省は学習指導要 領の中で、どのような教授法を使えばよいかという具体的な指針を明示してはいない が、この悉皆研修の計画案や報告を見る限り、CLTが推奨されていたことがわかる (悉皆研修について詳しくは新英語教育編集部, 2008; 卯城, 2003)。しかし、このよう な一連のコミュニカティブな授業をめざす英語教育改革が、実際の教育現場に浸透 しているかどうかが問題である。 
CLTがどのように理解され実践されてきたかについての調査は、1989年学習指導 要領の実施 (1993年) 以来様々な形で行われたが、いずれも日本の高等学校でのCLT の実現の難しさを報告している。Gorsuch (2000b) は、将来コミュニケーション能力を 評価するべく入試改革が行われたとしても、即授業実践に影響するのではなく、学校 環境や教室環境に変化をもたらすことで、徐々に実践に影響が及ぶのではないかと 予測した。Sakui (2004) は、文法中心の授業とコミュニカティブな授業を両立させよう と制約の多い教育環境の中で努力する教員の姿を “wearing two pairs of shoes” (p. 155) と表現した。Kikuchi and Browne（2009）は学習指導要領と高等学校で実際に行 われている授業との乘離を指摘した。このように、1980年度からの様々な改革をもつ てしても、CLTの普及が難しい現状の中、文部科学省は2009年の学習指導要領で、 「高校の英語の授業では基本的に英語で行う」と定めた (文部科学省，2009）。これが 実施されるのは2013年であるが、現場でどのようにこれを受け止めるかがすでに議論 の的となっている(弘山, 2009)。

\section{研究目的と研究課題}

先行研究によれば、CLTが日本の高等学校でまだ広く実践されてこなかった事実 は否めない。しかるに、コミュニカティブな授業が推奨されて以来約20年を経、行動 計画により悉皆研修が実施された現在、現場の英語教師がCLTをどのように考え実 践しているかについて全国的調査はなされていない。また、言語教師の認知や信条に 影響を及ぼす学習経験、教員専門研修、教育環境など様々な要因についての包括的 調査も行われてこなかった。そこで、Borg (2003) の言語教師認知研究への提案 (特 定の教え方に焦点をあて、中学高校の外国語教師を扱う）を鑑み、英語教育改革の実 態と今後の展望を探るべく、日本人高校教師のCLTに関する信条と実践、および教師 自身の能力や経験、教育環境などについての認識について調査した。研究課題は次の 3つから成る。

1. 日本人高校教師はCLTに関してどのような信条をもっているか。

2. 日本人高校教師はCLTをどのように実践しているか。

3. 日本人高校教師は、自分自身の英語教師としての能力、教職課程、教員研 修、教育環境、学習経験をどのように受けとめているか。

\section{研究の方法}

本論文のデー夕は主研究 (Nishino, 2009)の一部である。主研究では質問票調査、 授業観察、インタビューの3つの方法を用いたが、本論文では質問票調査の結果のみ 扱う。

\section{調查協力者}

調査協力者は、無作為抽出された高等学校 ${ }^{4}$ で英語I・II を教える日本人高校教員 139名である。男性76名、女性61名、無回答2名であった。14名(全体の約10\%)が教 員主催の研究会に属しており、112名は属しておらず、13名が無回答であった。教員 
経験はそれぞれ:1〜10年、56名;11〜20年、29名;21～30年、33名; 31〜 44年、18名; 無回答、3名であった。

\section{質問票}

質問票は主にBrown(2001)、Nishino（2008）を基に作成した。A〜Hの8パートから 成り、69項目の選択式回答 (パートA〜G) (表 1 参照) と3項目の記述式回答 (パート $\mathrm{H}$ )を求めた。質問の内容は、教師のCLTに関する信条(パートA)、英語教師としての 能力 (英語運用能力、授業運営能力、授業管理能力を含む) についての認識 (B)、教 職課程 (C)、教員研修 (D)、教育環境(教室環境、学校環境、社会環境を含む) (E)、 授業実践 $(\mathrm{F}) 、$ 学習経験 $(\mathrm{G})$ である。パートAとパートHは研究課題 1、パートFは研

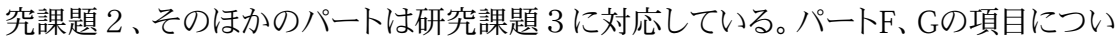
ては 5 つの選択肢 $(1=$ 全然〜ない、 $2=$ あまり〜ない、 $3=$ 時々、 $4=$ たいてい、 $5=よ く$ )を、ほかのパートについては 6 つの選択肢(パートA、C、D、Eでは、1＝強 <反対、 $2=$ 反対、 $3=$ やや反対、 $4=$ まあ賛成、 $5=$ 賛成、 $6=$ 強く賛成) (パート Bでは、 $1=$ 全くそう思わない、 $2=$ そう思わない、 $3=$ あまりそう思わない、 $4=や$ やそう思う、 $5=$ かなりそう思う、6＝そう思う)を設けた。

2006年4月と8月に予備調査を実施し、その都度質問票を改訂し2006年11月本調査 に臨んだ。

\section{データ分析}

本研究の分析の方法は以下の通りである。

研究課題 1 ：質問票パートAの回答を項目ごとに度数分布表 (\%)で示し、パートH については項目ごとに回答数とその割合を表にまとめた。

研究課題 2：質問票パートFの回答を項目ごとに度数分布表(\%)で示した。

研究課題 3 ：質問票パートDとパートE (E2, E8, E12, E14〜E17)の回答を項目ごとに 度数分布表 $(\%)$ で示した。また、2つの統計分析(パートBの英語教師 としての能力について 10 群間の一元配置分散分析と、パートCの教 職課程とパートDの教員研修でのCLTの扱い方を比較する $\mathrm{t}$ 検定)を 行った。有意水準 ( $\alpha$ 值) は.05と定めた。

\section{結果}

2007年1月、質問票回答を142通受け取った時点で分析を始めた。回答率は13\% で、謝礼なしの質問票の平均回答率にほぼ同率となった(萩原, 太田, 藤井, 2006)。 3通の回答が不完全であったため139通をデータとして用いた。信頼度はCronbach's $\alpha=.89$ であった。項目ごとの記述統計は表 1 に示す。 


\section{表 1. 質問票項目ごとの記述統計量 $(N=139)$}

\begin{tabular}{|c|c|c|c|}
\hline & & $\begin{array}{c}\text { 平均 } \\
\text { 值 }\end{array}$ & $\begin{array}{l}\text { 標準 } \\
\text { 偏差 }\end{array}$ \\
\hline A1 & 言葉は、何かを行うために使う時に効果的に習得される。 & 5.23 & 0.78 \\
\hline A2 & $\begin{array}{l}\text { 外国語学習では、実際の生活でコミュニケーションできる能力を育てるこ } \\
\text { とが大切だ。 }\end{array}$ & 4.83 & 0.80 \\
\hline A3 & 授業中、生徒は英語で実際にコミュニケーションをとるべきだ。 & 4.33 & 0.95 \\
\hline A4 & 生徒の英語の正確さを伸ばすと同じく流暢さを伸ばすことも重要だ。 & 4.23 & 0.95 \\
\hline A5 & CLTの授業では、先生は生徒のコミュニケーション活動を手助けすべきだ。 & 4.76 & 0.76 \\
\hline A6 & 外国語学習では暗記が重要な役割を果たす。 & 4.82 & 0.83 \\
\hline A7 & グループワークやペアワークは生徒の英語学習を助ける役割を持つ。 & 4.51 & 0.90 \\
\hline A8 & $\begin{array}{l}\text { 完璧な発音をめざすのではなく、理解可能な英語の発音をめざすこと } \\
\text { が、適切な目標となる。 }\end{array}$ & 4.76 & 0.94 \\
\hline A9 & $\begin{array}{l}\text { 外国語学習は試行錯誤の経過をたどるので、間違えることは学習の一環 } \\
\text { だと考えるべきだ。 }\end{array}$ & 5.30 & 0.69 \\
\hline A10 & $\begin{array}{l}\text { 生徒の英語を使おうとする動機づけは、コミュニケーション活動によって } \\
\text { 強まる。 }\end{array}$ & 4.60 & 1.00 \\
\hline B1 & 高校の英語教師として十分な英語の聞く力があると思う。 & 4.01 & 1.01 \\
\hline B2 & 高校の英語教師として十分な英語の話す力があると思う。 & 3.86 & 1.06 \\
\hline B3 & 高校の英語教師として十分な英語の読む力があると思う。 & 4.19 & 0.88 \\
\hline B4 & 高校の英語教師として十分な英語の書く力があると思う。 & 3.98 & 0.99 \\
\hline B5 & 高校の英語教師として十分な英語の文法知識があると思う。 & 4.39 & 0.91 \\
\hline B6 & 英語圏の文化について生徒に話をするのに十分な知識があると思う。 & 3.82 & 1.17 \\
\hline B7 & $\begin{array}{l}\text { 生徒がグループワークやペアワークをやるときに、生徒の行動をきちんと } \\
\text { 管理できると思う。 }\end{array}$ & 3.79 & 0.96 \\
\hline B8 & 生徒が楽しめるような英語のアクティビティを与えていると思う。 & 3.49 & 1.03 \\
\hline B9 & 生徒の英語でのコミュニケーション活動を適切に手助けしていると思う。 & 3.49 & 1.04 \\
\hline $\mathrm{B} 10$ & コミュニケーション活動で、生徒の自主性を尊重していると思う。 & 3.59 & 0.94 \\
\hline $\mathrm{C} 1$ & CLTが推奨された。 & 3.20 & 1.34 \\
\hline $\mathrm{C} 2$ & 第二言語習得の知識が深まつた。 & 3.59 & 1.27 \\
\hline $\mathrm{C} 3$ & グループワークやペアワークのやり方が上達した。 & 2.69 & 1.21 \\
\hline $\mathrm{C} 4$ & コミュニケーション活動に必要な教材が提供された。 & 2.78 & 1.28 \\
\hline C5 & CLTの授業を観察する機会を与えられた。 & 2.46 & 1.31 \\
\hline C6 & CLTを使って模擬授業する機会を与えられた。 & 2.30 & 1.29 \\
\hline D1 & CLTが推奨された。 & 4.22 & 1.20 \\
\hline D2 & 第二言語習得の知識が深まつた。 & 3.46 & 1.35 \\
\hline D3 & グループワークやペアワークのやり方が上達した。 & 3.56 & 1.18 \\
\hline D4 & コミュニケーション活動に必要な教材が提供された。 & 3.76 & 1.19 \\
\hline D5 & CLTの授業を観察する機会を与えられた。 & 3.79 & 1.27 \\
\hline D6 & CLTを使つて模擬授業する機会を与えられた。 & 3.10 & 1.37 \\
\hline
\end{tabular}




\begin{tabular}{|c|c|c|c|}
\hline & $\begin{array}{c}\text { 平均 } \\
\text { 值 }\end{array}$ & $\begin{array}{l}\text { 標準 } \\
\text { 偏差 }\end{array}$ \\
\hline E1 & 生徒は大学入試に向けて懸命に勉強する。 & 2.87 & 1.56 \\
\hline E2 & 生徒は英語I・IIの授業でコミュニケーション活動をすることを望んでいる。 & 3.34 & 1.13 \\
\hline E3 & 生徒は英語I・IIの授業で文法と訳読を学ぶことを望んでいる。 & 3.69 & 1.16 \\
\hline E4 & 1 クラスの生徒の人数はコミュニケーション活動をするのに適している。 & 2.46 & 1.26 \\
\hline E5 & 先生は独自のシラバスに沿って授業をしてよい。 & 3.77 & 1.28 \\
\hline E6 & 保護者は生徒に大学入試のために懸命に勉強することを望んでいる。 & 3.53 & 1.58 \\
\hline E7 & 教材を用意する時間が十分ある。 & 2.98 & 1.24 \\
\hline E8 & 生徒はグループワークやペアワークで使う英語を理解することができる. & 3.20 & 1.14 \\
\hline E9 & 文部科学省検定教科書はコミュニケーション活動に役立つ。 & 3.24 & 1.06 \\
\hline E10 & 英語I・IIの授業に使う教室では視聴覚機器が使える。 & 3.90 & 1.36 \\
\hline E11 & コミュニケーション活動に使える教材が揃つている。 & 2.82 & 1.21 \\
\hline E12 & 生徒は講義型の授業より、グループワークやペアワークを好む。 & 3.66 & 1.08 \\
\hline E13 & 英語I・IIの授業数は適切である。 & 3.38 & 1.19 \\
\hline E14 & 学習指導要領が英語I・IIの授業に影響を与えている。 & 3.60 & 1.05 \\
\hline E15 & $\begin{array}{l}\text { 学習指導要領がオーラル・コミュニケーションI・IIの授業に影響を与えて } \\
\text { いる。 }\end{array}$ & 3.61 & 1.11 \\
\hline E16 & $\begin{array}{l}\text { 2006年度のセンター試験でのリスニングテストの導入が英語I・IIの授業 } \\
\text { に影響を与えている。 }\end{array}$ & 3.48 & 1.30 \\
\hline E17 & $\begin{array}{l}2006 \text { 年度のセンター試験でのリスニングテストの導入がオーラル・ } \\
\text { コミュニケーションI・IIの授業に影響を与えている。 }\end{array}$ & 3.52 & 1.31 \\
\hline \multicolumn{2}{|r|}{ 英語I・IIのクラスで: } & \multirow{2}{*}{2.74} & \multirow{2}{*}{1.16} \\
\hline F1 & クラスルーム・イングリッシュを使う。 & & \\
\hline $\mathrm{F} 2$ & オーラル・イントロダクションで教科書の内容を説明する。 & 2.26 & 1.03 \\
\hline F3 & 生徒にスピーチやプレゼンテーションをさせる。 & 1.94 & 0.89 \\
\hline F4 & 生徒にエッセイや物語を書かせる。 & 1.68 & 0.87 \\
\hline F5 & 生徒に教科書の要約を英語で書かせる。 & 1.64 & 0.87 \\
\hline F6 & 生徒に教科書の内容を英語で質問する。 & 2.80 & 1.23 \\
\hline F7 & $\begin{array}{l}\text { 英語のアクティビティを使う。例）ロールプレイ、インフォメーション・ } \\
\text { ギャツプなど }\end{array}$ & 2.35 & 0.97 \\
\hline F8 & 英語の歌やゲームを使う。 & 2.47 & 1.11 \\
\hline F9 & 英語の映画やドラマを見せる。 & 2.14 & 1.09 \\
\hline & 英語でのグループワークやペアワークを使う。 & 2.47 & 1.09 \\
\hline \multicolumn{2}{|r|}{ 高校時代に英語の先生は: } & \multirow{2}{*}{1.75} & \multirow{2}{*}{0.99} \\
\hline G1 & クラスルーム・イングリッシュを使った。 & & \\
\hline G2 & オーラル・イントロダクションで教科書の内容を説明した。 & 1.50 & 0.83 \\
\hline & 生徒にスピーチやプレゼンテーションをさせた。 & 1.40 & 0.76 \\
\hline G4 & 生徒にエッセイや物語を書かせた。 & 1.40 & 0.74 \\
\hline G5 & 生徒に教科書の要約を英語で書かせた。 & 1.45 & 0.78 \\
\hline
\end{tabular}




\begin{tabular}{llccc}
\hline & & 平均 & 標準 \\
& 值 & 偏差 \\
\hline G6 & 生徒に教科書の内容を英語で質問した。 & 1.84 & 1.13 \\
G7 & 英語のアクティビティを使った。例)ロールプレイ、インフォメーション・ & 1.47 & 0.87 \\
& ギャップなど & & \\
G8 & 英語の歌やゲームを使った。 & 1.67 & 0.97 \\
G9 & 英語の映画やドラマを見せた。 & 1.48 & 0.90 \\
G10 英語でのグループワークやペアワークを使った。 & 1.48 & 0.89 \\
\hline
\end{tabular}

\section{CLTに関する信条 (研究課題 1)}

質問票のパートA (CLTに関する信条) では、A6 (暗記の重要性) 以外の項目をCLT の理念や特徵 (Brown, 2001) から選んだ。表2から、大多数の回答者がCLTに対し肯 定的な信条をいだいていることがわかる。A1（言葉は使うことで効果的に習得）、A2

(コミュニケーション能力の育成が大切)、A5（先生の役割はコミュニケーションの 手助け)、A8 (理解可能な発音が目標)、A9 (間違いは学習の一環)、A10 (動機づけ はコミュニケーション活動で強まる) などは57〜88\%から「強く賛成」または「賛成」 の支持を得ており、「まあ賛成」「賛成」「強く賛成」の割合を合計すると $90 \%$ 以上に なった。A3 (授業中のコミュニケーションの必要性)、A4（正確さと同様流暢さを伸 ばす重要性)、およびA7 (グループワークやペアワークが学習を助ける)については、 賛成の割合が他の項目に比べてやや低かったが、「まあ賛成」「賛成」「強く賛成」の 合計割合は80\%以上になった。A6に「強く賛成」、「賛成」した回答者が70\%近くいた ことも注目に值する。

表 2 . CLTに関する信条 $(N=139)$

\begin{tabular}{|c|c|c|c|c|c|c|c|}
\hline & & \multicolumn{2}{|l|}{ 強< } & \multicolumn{3}{|c|}{ やや まあ } & \multirow{3}{*}{$\begin{array}{c}\text { 強く } \\
\text { 賛成 } \\
\%\end{array}$} \\
\hline & & 反対 & 反対 & 反対 & 賛成 & 賛成 & \\
\hline & & $\%$ & $\%$ & $\%$ & $\%$ & $\%$ & \\
\hline $\mathrm{A} 1$ & $\begin{array}{l}\text { 言葉は、何かを行うために使う時に効果的に習 } \\
\text { 得される。 }\end{array}$ & 0 & 0 & 2 & 15 & 41 & 42 \\
\hline A2 & $\begin{array}{l}\text { 外国語学習では、実際の生活でコミュニケー } \\
\text { ションできる能力を㕕てることが大切だ。 }\end{array}$ & 0 & 0 & 3 & 33 & 42 & 22 \\
\hline A3 & $\begin{array}{l}\text { 授業中、生徒は英語で実際にコミュニケー } \\
\text { ションをとるべきだ。 }\end{array}$ & 1 & 2 & 12 & 44 & 30 & 11 \\
\hline A4 & $\begin{array}{l}\text { 生徒の英語の正確さを伸ばすと同じく流暢さを } \\
\text { 伸ばすことも重要だ。 }\end{array}$ & 2 & 3 & 11 & 47 & 30 & 7 \\
\hline A5 & $\begin{array}{l}\text { CLTの授業では、先生は生徒のコミュニケー } \\
\text { ション活動を手助けすべきだ。 }\end{array}$ & 1 & 0 & 2 & 30 & 54 & 13 \\
\hline A6 & 外国語学習では暗記が重要な役割を果たす。 & 0 & 1 & 4 & 28 & 47 & 20 \\
\hline A7 & $\begin{array}{l}\text { グループワークやペアワークは生徒の英語学習 } \\
\text { を助ける役割を持つ。 }\end{array}$ & 1 & 2 & 6 & 39 & 41 & 11 \\
\hline
\end{tabular}




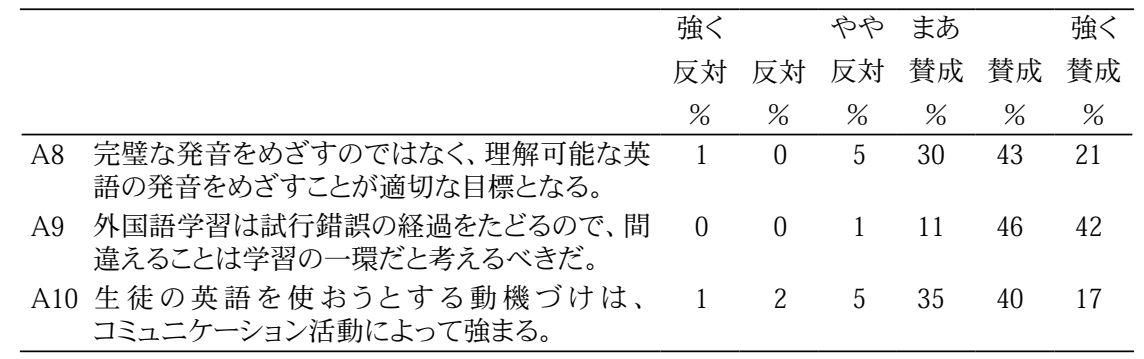

質問票のパートHでは以下の 3 つの質問をした:

1. 英語I・IIの教え方を改善したいと思っていらつしゃいますか。

2.「はい」答えた方はどんなところを変えたいですか。

3. 教え方を改善するには、教育環境の中で何を最初に変えなければいけないと お考えですか。

ここでは回答の中からCLTに関連するものを報告する。質問 1 に対する回答 は、139名中110名が「はい」、24名が「いいえ」、名が無回答であった。

質問 2 に対しては、質問 1 「はい」と答えた 110 名中 75 名が、コミュニカティブな 授業にしたいという趣旨の回答をしている。代表的なものは「生徒のコミュニケー ション能力を伸ばしたい」(15名)、「もっとたくさん英語を使いたい」（14名）、「コ ミュニケーション活動を増やしたい」(10名) などである。また、7名が「訳読を使わず に読み取りの力をつけたい」という希望を述べている。「生徒が英語に触れる機会を 多くする」（2名）、「英語で理解する力をつける」（1名）などからも訳読を使わずに英 語のインプットを増やしたいという意向がうかがえる。さらに「技能をバランスよく 教える」（6名）も、音声を指導しない訳読からの脱皮を暗示し、これに関連する回答 として5名が「リスニングを入れる」「ペアワークを入れる」「音声重視にする」などの 希望を述べている (表 3 参照)。

表 3 . 英語I·IIの授業についての改善点 $(N=75)$

\begin{tabular}{lcc}
\hline 教授法・授業実践 & 回答者数 & $\%$ \\
\hline 生徒のコミュニケーション能力を伸ばす。 & 15 & 20 \\
授業中(教師が)もつと英語を使う。 & 14 & 19 \\
コミュニケーション活動をより多く取り入れる。 & 10 & 13 \\
訳読を使わずに読み取りの力をつける。 & 7 & 10 \\
4技能をバランスよく教える。 & 6 & 8 \\
生徒が英語を話す時間を多くとる。 & 6 & 8 \\
生徒中心型授業にする。 & 4 & 5 \\
ペアワークを多く使う。 & 2 & 3 \\
リス二ングを多く入れる。 & 2 & 3 \\
生徒が英語に触れる機会を多くする。 & 2 & 3
\end{tabular}




\begin{tabular}{lcc}
\hline 教授法・授業実践 & 回答者数 & $\%$ \\
\hline アウトプットとインプットをバランス良く扱う。 & 2 & 3 \\
英語で理解する力をつける。 & 1 & 1 \\
音声重視にする。 & 1 & 1 \\
自己表現力をつける。 & 1 & 1 \\
英語圈の文化を教える。 & 1 & 1 \\
サマリーライテイングをさせる。 & 1 & 1 \\
\hline
\end{tabular}

また、質問 3 については、コミュニカティブな授業にしたいと答えた 75 名のうち、最 多数 (20名)が最初に改善すべき点として「1クラスの生徒数」をあげ、それに続いて10 名が「大学入試」をあげた(表 4 参照)。さらに特筆すべきは、教師をとりまく教育環境 の改善を望んでいることであろう。代表的なものに「教材研究の時間」(6名)、「教員研 修」(2名)などがあげられる。

\section{表 4 .コミュニカティブな授業を行うための改善点 $(N=75)$}

\begin{tabular}{lcc}
\hline 改善点 & 回答者数 & $\%$ \\
\hline 1クラスの生徒数 & 20 & 27 \\
大学入試 & 10 & 15 \\
教師の教材研究の時間 & 6 & 8 \\
教師の言語教育への考え方や態度 & 6 & 8 \\
生徒の英語力や学習態度、意欲 & 6 & 8 \\
教師の能力 (英語力も含む)、知識 & 4 & 5 \\
授業時間数 & 4 & 5 \\
シラバス & 2 & 3 \\
同僚の協力 & 2 & 3 \\
教員研修 & 2 & 3 \\
教師の英語力 & 1 & 1 \\
学習指導要領 & 1 & 1 \\
文部科学省検定教科書 & 1 & 1 \\
施設 (視聴覚室、LL教室など) & 1 & 1 \\
ALTの人数を増やす & 1 & 1 \\
教員採用制度 & 1 & 1 \\
その他 (国語教育、社会の理解、国民性) & 3 & 4 \\
無回答 & 4 & 5 \\
\hline
\end{tabular}

\section{CLTの実践 (研究課題 2)}

質問票のパートFでは英語I・IIの教室で行われるコミュニケーション活動溹扱っ た。表 5 から、コミュニケーション活動があまり使われていないことがわかる。普段の 授業で使っていると考えられる回答者(「たいてい使う」と「よく使う」と答えた人)の割 
合が20\%を超えたのはF1(クラスルーム・イングリッシュ) とF6 (教科書の内容について の質問応答)のみであった。タスク(F7)やグループワークやペアワーク(F10) は第二 言語習得を促すと提唱されているが(Doughty \& Pica, 1986)、これらの項目に「たい てい使う」「よく使う」と回答した人の割合は低く、それぞれ9〜14\%であった。また、F4 (エッセイ、物語)、F5 (教科書の要約)については半数以上が「全然使わない」と答え た。

表 5 . 高校英語I・IIで使われているコミュニケーション活動 $(N=139)$

\begin{tabular}{|c|c|c|c|c|c|c|}
\hline & & $\begin{array}{c}\text { 全然使 } \\
\text { わない } \\
\%\end{array}$ & $\begin{array}{c}\text { あまり使 } \\
\text { わない } \\
\%\end{array}$ & $\begin{array}{c}\text { 時々 } \\
\text { 使う } \\
\%\end{array}$ & $\begin{array}{c}\text { たいてい } \\
\text { 使う } \\
\%\end{array}$ & $\begin{array}{c}\text { よく } \\
\text { 使う } \\
\%\end{array}$ \\
\hline F1 & ラスルーム・イングリッシュ & 14 & 32 & 28 & 17 & 9 \\
\hline $\mathrm{F} 2$ & オーラル・イントロダクション & 27 & 36 & 24 & 12 & 1 \\
\hline F3 & スピーチ、プレゼンテーション & 36 & 40 & 20 & 3 & 1 \\
\hline $\mathrm{F} 4$ & エッセイ、物語を書く & 51 & 37 & 9 & 1 & 2 \\
\hline F5 & 教科書の要約を書く & 54 & 36 & 6 & 2 & 2 \\
\hline F6 & 教科書の内容についての質問応答 & 20 & 17 & 36 & 17 & 10 \\
\hline F7 & $\begin{array}{l}\text { タスク(インフォメーション・ギャッ } \\
\text { プ等） }\end{array}$ & 23 & 31 & 37 & 7 & 2 \\
\hline F8 & ゲーム、歌 & 24 & 24 & 39 & 7 & 6 \\
\hline F9 & 映画、ドラマ鑑賞 & 34 & 32 & 24 & 6 & 4 \\
\hline F10 & グループワーク、ペアワーク & 23 & 25 & 38 & 10 & 4 \\
\hline
\end{tabular}

\section{英語教師としての能力、教職課程、教員研修、教育環境、学習経験 (研究課題 3)}

質問票のパートBでは教師が自分の能力をどうとらえているかを調べた。B1(聞く 力)、B2 (話す力)、B3 (読む力)、B4 (書く力)、B5(文法の知識)、B6 (英語圈文化につ いての知識)、B7(グループワークやペアワークの際の授業管理能力)、B8(楽しいアク ティビティを生徒に提供)、B9(生徒のコミュニケーション活動を適切に援助)、B10(コ ミュニケーション活動の際に生徒の自主性を尊重)の10項目である。CLTの指導に関 係する項目 (B8、B9、B10)への回答の平均値が6段階評価の3.49〜3.59で、英語力に 関する項目 $(B 1 \sim B 5) へ の$ 回答の平均值3.86〜4.39に比べて低い值を示した(表 1 参 照)。そこでB1〜B10の10項目を独立変数として一元配置分散分析を行った結果、群 間に有意差が認められ、効果量(偏イータ 2 乗)は.07であった(表 6 参照)。

追加分析 (Dunnett's C)により次の20組のペアに有意差が検出された:

1. B5 (文法の知識) と8項目 (B1:聞く力、B2:話す力、B4:書く力、B6:文化につ いての知識、B7:授業管理能力、B8:アクティビティの提供、B9:コミュニケー ション活動の援助、B10:自主性の尊重)とのペア8組。

2. 英語力に関する3項目 (B1:聞く力、B3:読む力、B4:書く力) とCLTの指導に 関係する3項目 (B8:アクティビティの提供、B9:コミュニケーション活動の援 助、B10:自主性の尊重)との組み合わせでできるぺア 9 組。

3. B7 (授業管理能力) とCLTの指導に関係する3項目とのペア3組。 
$1 \sim 3$ の組み合わせで、先に示した項目 ( 1 では文法の知識、2では聞く、読む、 書く力、3では授業管理能力)の平均值の方が高かった(表 1 参照)。すなわち、(1) 法の知識を、読む力以外のすべての能力より高く評価し、(2)CLTの指導に関係する 能力を、聞く、読む、書く力や授業管理能力よりも低く評価していることがわかる。

表 6. 分散分析表:英語教師としての能力に関する認識のちがい $(N=139)$

\begin{tabular}{lcrcccc}
\hline & 自由度 & 平方和 & 平均平方 & 值 & 有意確率 & 偏イー夕2乗 \\
\hline グループ間 & 9 & 110.08 & 12.23 & 12.20 & .000 & .07 \\
グループ内 & 1380 & 1383.61 & 1.00 & & & \\
合計 & 1389 & 1493.70 & & & & \\
\hline
\end{tabular}

注. 偏イー夕2乗 $=$ 効果量

質問票のパートCとパートDは、それぞれ教職課程 (大学) と教員研修の場で、CLT がどう扱われたかを尋ねている:C1とD1 (CLTの推奨)、C2とD2(第二言語習得の知 識の深まり)、C3とD3(グループワークやペアワークのやり方が上達)、C4とD4(コミュ ニケーション活動に必要な教材の提供)、C5とD5 (CLTの授業を観察)、C6とD6 (CLT を使っての模擬授業)。C2とD2のペアを除いて、他の5組のペアは教員研修に関する 回答の平均值の方が教職課程に関するものより高い值を示した。t検定の結果 (ボン

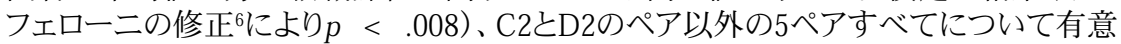
差がみられ、効果量(偏イータ2乗)は.09〜.21であった(表7参照)。この結果から、大 学の教職課程では、CLTの実践的指導が教員研修の場よりも少ないと受けとめられ ていたことがわかる。

表 7 . 教職課程と教員研修のCLTの扱い方のちがい $(N=139)$

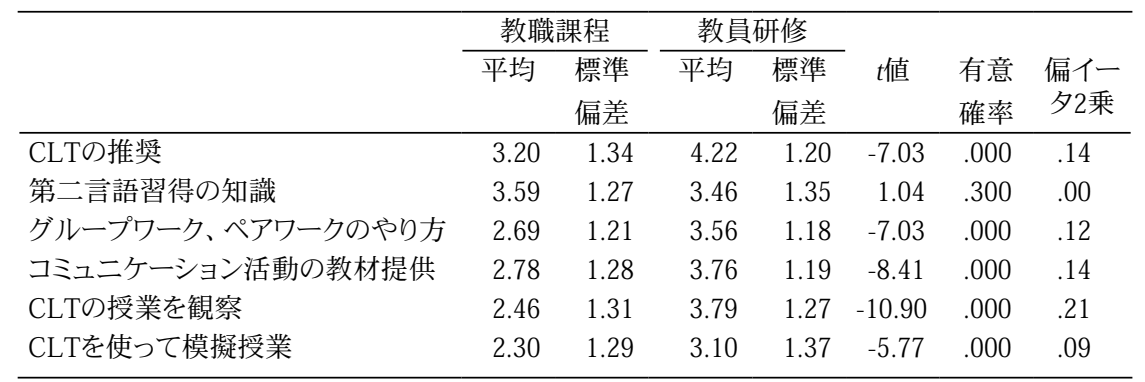

注. 偏イー夕2乗 $=$ 効果量

それでは教員研修ではCLTがどのように扱われていたのだろうか。パートDへの 回答(表 8 )をみるとD1 (CLTが推奨されていた)に賛成(「強く賛成」、賛成」)した 割合は47\%になり、「まあ賛成」の割合を合計すると80\%が賛同を示している。逆にD6 (CLTを使っての模擬授業)については、反対(「強く反対」「「反対」)が $39 \%$ を占めて 
いる。その他の内容(第二言語習得の知識、グループワークやペアワーク、教材、授業

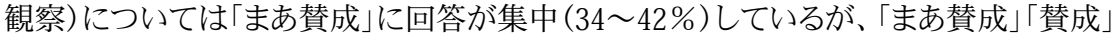
「強く賛成」を合計すると $60 \%$ 前後の回答者が、教員研修でCLTが扱われていたこと に賛成している。

表 8. 教員研修でのCLTに関する内容 $(N=139)$

\begin{tabular}{|c|c|c|c|c|c|c|c|}
\hline & & $\begin{array}{c}\text { 強< } \\
\text { 反対 } \\
\%\end{array}$ & $\begin{array}{c}\text { 反対 } \\
\%\end{array}$ & $\begin{array}{c}\text { やや } \\
\text { 反対 } \\
\%\end{array}$ & $\begin{array}{c}\text { まあ } \\
\text { 賛成 } \\
\%\end{array}$ & $\begin{array}{c}\text { 賛成 } \\
\%\end{array}$ & $\begin{array}{c}\text { 強< } \\
\text { 賛成 } \\
\% \\
\%\end{array}$ \\
\hline D1 & CLTの推奨 & 3 & 9 & 8 & 33 & 37 & 10 \\
\hline D2 & 第二言語習得の知識 & 13 & 12 & 18 & 35 & 19 & 3 \\
\hline D3 & グループワーク、ペアワークのやり方 & 6 & 16 & 17 & 42 & 17 & 2 \\
\hline D4 & コミュニケーション活動の教材提供 & 5 & 13 & 15 & 42 & 20 & 5 \\
\hline D5 & CLTの授業を観察 & 5 & 14 & 17 & 34 & 22 & 8 \\
\hline D6 & CLTを使って模擬授業 & 13 & 26 & 19 & 27 & 11 & 4 \\
\hline
\end{tabular}

質問票のパートEは教育環境についての質問だが、ここではコミュニケーション活 動に関わる教室環境(生徒の実態とクラスサイズ)と、社会環境(教育政策の影響)の 2点に焦点を当てる。

まず、回答者はコミュニケーション活動に関わる教室環境をどのようにとらえている だろうか。表 9 によると、E2（生徒はコミユニケーション活動をすることを望んでいる）に

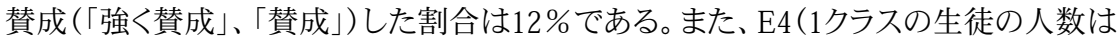
コミュニケーション活動をするのに適している)、及びE8(生徒はグループワークやペア ワークで使う英語を理解することができる)についても、賛成(「強く賛成」「賛成」)した 回答者はそれぞれ6\%、10\%、と低い割合を示している。特にE4については反対(「強く 反対」、「反対」）した割合が $57 \%$ 高い割合を示した。回答者の多くは、教室環境がコ ミュニケーション活動に適していないと考えているようだ。

\section{表 9.コミュニケーション活動に関わる教室環境 (生徒の実態、クラスサイズ) $(N=139)$}

\begin{tabular}{cccccccc}
\hline & & $\begin{array}{c}\text { 強く } \\
\text { 反対 } \\
\%\end{array}$ & $\begin{array}{c}\text { 反対 } \\
\%\end{array}$ & $\begin{array}{c}\text { やや } \\
\text { 反対 } \\
\%\end{array}$ & $\begin{array}{c}\text { まあ } \\
\text { 賛成 } \\
\%\end{array}$ & $\begin{array}{c}\text { 賛成 } \\
\%\end{array}$ & $\begin{array}{c}\text { 強く } \\
\text { 賛成 } \\
\%\end{array}$ \\
\hline E2 & $\begin{array}{l}\text { 生徒は英語I・IIの授業でコミュニケー } \\
\text { ション活動をすることを望んでいる。 }\end{array}$ & 7 & 15 & 27 & 39 & 10 & 2 \\
E4 & $\begin{array}{l}\text { 1クラスの生徒の人数はコミュニケー } \\
\text { ション活動をするのに適している。 }\end{array}$ & 27 & 30 & 22 & 15 & 5 & 1 \\
E8 & $\begin{array}{l}\text { 生徒はグループワークやペアワークで } \\
\text { 使う英語を理解することができる。 }\end{array}$ & 8 & 19 & 29 & 34 & 9 & 1 \\
\hline
\end{tabular}

文部科学省の政策の影響 (項目E14〜E17)については、「まあ賛成」に回答が集中 しており、E14(学習指導要領が英語I・IIに影響) : 49\%、E15(学習指導要領がオー 
ラル・コミュニケーションI・IIに影響) :45％、E16(センター試験でのリスニングテスト の導入が英語I・IIに影響) $: 33 \% 、 E 17$ (センター試験でのリスニングテストの導入が オーラル・コミュニケーションI・IIに影響): $33 \%$ であった(表10参照)。「まあ賛成」「賛 成」「強く賛成」の割合の合計はそれぞれE14:62\%、E15:60\%、E16:55\%、E17:55\% で、60\%前後の回答者が、程度こそ違え文部科学省の政策の影響を感じているとい える。

表 10. 学習指導要領とセンター試験リスニングテストの英語授業への影響 $(N=139)$

\begin{tabular}{|c|c|c|c|c|c|c|}
\hline & \multicolumn{2}{|l|}{ 強< } & \multirow{2}{*}{$\begin{array}{l}\text { やや } \\
\text { 反対 }\end{array}$} & \multicolumn{2}{|l|}{ まあ } & \multirow{2}{*}{$\begin{array}{l}\text { 強< } \\
\text { 賛成 }\end{array}$} \\
\hline & 反対 & 反対 & & 賛成 & 賛成 & \\
\hline & $\%$ & $\%$ & $\%$ & $\%$ & $\%$ & $\%$ \\
\hline E14 学習指導要領が英語I・IIに影響 & 4 & 12 & 22 & 49 & 9 & 4 \\
\hline E15 学習指導要領がOC I・IIに影響 & 5 & 8 & 27 & 45 & 10 & 5 \\
\hline E16 リスニングテスト導入が英語I・IIに影響 & 9 & 15 & 21 & 33 & 18 & 4 \\
\hline E17リスニングテスト導入がOC I・IIに影響 & 9 & 13 & 23 & 33 & 17 & 5 \\
\hline
\end{tabular}

注. OC = オーラル・コミュニケーション

質問票のパートGでは、高校時代のCLTの経験について尋ねた(表 1 参照)。平均 值が5段階評価の 1.40 (標準偏差 = 0.74) から1.84（標準偏差 = 1.13）であるから、すべ ての項目について高校時代の英語の先生はコミュニケーション活動を「使わなかった」 （あまり使わなかった、全然使わなかった）に回答が集中していることがわかる。回答 者の最年少は2005年以降に大学卒業、現役合格なら1998年に高校に入学したことに なるが、その当時、コミュニカティブな授業は稀であっただろう。したがって回答者の ほとんどが高校時代にコミュニケーション活動を経験していないという結果になった ものと考えられる。7

調査の結果をまとめると、CLTに関する教員の認知と実践には乘離があり、回答者 は自分自身のCLTの指導力をさまざまな能力より低いと認識し、教職課程でCLTにつ いての指導が少なかったと感じている。回答者自身は高校時代にコミュニケーション 活動をあまり経験していない。また、教室環境がコミュニケーション活動に適していな いと受けとめている回答者が多い。文部科学省の政策については、半数以上がその 影響を多かれ少なかれ感じている。以上を踏まえ、次の章では研究課題 1 〜につ いて順に考察したい。

\section{考察}

\section{日本人高校教師はCLTに関してどのような信条をもっているか。}

結果で述べたように、回答者の多くはCLTに関して肯定的な信条をもっている。「や や賛成」を含めれば、質問票のパートAにおける全ての項目に8割以上が賛同した。先 に述べたように、CLTは具体的な教授法ではなく言語教育の基礎となる理論である ため、回答者の多くは理論としてのCLTを肯定的にとらえている、と解釈できるであろ う。 
また、CLTの理念や特徵 (Brown, 2001) とは関連のない項目のA6(外国語学習で は暗記が重要な役割を果たす)に強く賛成、または賛成した回答者は7割近くいた。 暗記が重要であるという信条が、訳読などの伝統的教授法に基づいているのか、コ ミュニケーション活動の中で表現や文の構造を覚えていくことが大切という考えに根 ざしているのか、あるいはその両方か、本質問票の結果だけでは明らかにできない。 さらなる調査が必要である。

さらに考察に值するのは、パートHの回答で、139名中75名がコミュニカテイブな授 業をしたいと願つていることである。「生徒のコミュニケーション能力を伸ばしたい」「 コミュニケーション活動を増やしたい」というように、生徒の活動を増やしてコミュニ ケーション能力をつけたいと望んでいる。そしてそのために最初にやるべきことは、1 クラスの生徒数を減らすことと答えた回答者が一番多く (20名)、次いで入試の改善 (10名) となる。これと同じ傾向はNishino(2008)も報告している。本調査の回答者に 限らず、多くの教師が、コミュニカティブな授業の実現を望んでおり、そのために目の 前にあるクラスサイズの問題をまず解決してほしいと願っている可能性がある。

確かに1クラスの人数を減らすには多大な予算が必要である。江利川 (2009)によれ ば、小中学校の 40 人学級を 30 人学級にするために、約 7800 憶円の予算が必要となる。 ちなみに2007年のOECDの調査によると、日本の教育機関への公的支出が国内総生 産に占める割合は3.4\%、OECD加盟国28力国中で最下位である(OECD, 2010)。他国 との支出割合の比較のみで議論することは危険ではあるが、日本では教育予算がもつ 亡優先されるべき状況にあるという事実は否めないだろう。クラスサイズを小さくすれ ば、教員の教室内での指導がやりやすくなり、授業以外での教員の負担も減る8。結果 としてOECD加盟国中最長といわれている日本の教師の労働時間(江利川)も減り、教 材研究や教員研修に取り組む時間的余裕もできるだろう。付け加えるならば、このよう な教員の時間的余裕の獲得も、本調査の回答者が改善事項として指摘している。

\section{日本人高校教師はCLTをどう実践しているか。}

研究課題 1 と研究課題 2 の結果を合わせみて、高校教員のCLTに対する信条と 実践に乘離がみられた。回答者の多くはCLTの理念に賛同しているが、実際にはコ ミュニケーション活動をあまり行っていない。CLTで有効とされるタスクやグループ ワークやペアワークなどを利用する回答者は少ない。また、エッセイ、物語、要約など を書く活動については半数以上が全く行わないと答えた。これらは進学校の場合、 ライティングの授業で主に行われている可能性があるが、英語I・IIでは4技能の総合 的な力を伸ばすのが目的である(文部省, 1999)ことを考えると、半数以上の教員がこ れらの活動を全く使っていないことは問題であろう。

Borg (2006)は、教員には「理想的な信条」(何をすべきか)と「現実的な信条」(何 ができるか)があり、制約の多い教育環境の中で両者を調整しつつ実践していると述 べている。また、Phipps and Borg(2009)は「核となる信条」と「付随的な信条」を定義 し、核となる信条は教師の経験に基づき、付随的な信条は理論に基づき形成される のが一般的であるとした。いずれにしても教師の信念体系が複雑であるために、イン タビューやアンケートの答えだけでは信条と実践の間にずれが生じることがある。こ の現象が本調査にも現れているといえる。質問票では主にCLTに関する信条のみ尋 
ねたために実践との間に乘離が生じた。教師が様々な教え方についてどのような信 条をもち、それらが実践にどのように影響しているかを、今後調査すべきである。

もう一点、信条と実践との乘離の原因として、教育環境の実践への影響があげら れる。CLTに賛成しそれを実現したくても、教育現場での制約(1クラスの人数、大学 入試など)があるためCLTが使いにくい現状であることは、記述式回答の中から垣間 見られた。本調査の質問票回収率は $13 \%$ であことから、回答した教員は、CLTに興 味がある、或いは授業改善に熱心である意欲的な教師であろう。そのような教師でさ えコミュニケーション活動を普段あまり使わないのだから、日本全体の高校でCLTが 普及していないこと、そして文部科学省の政策と教室の現実とにギャップがあること は明らかであろう。それゆえ現状を打開するには、CLTの実践に教育環境がどのよう に影響するかを探ることも必要である。研究課題 3 の考察でその一部を論じる。

また、CLTがあまり使われていない状況で注目すべきは、クラスルーム・イングリッ シュと質問応答が他の活動に比べて比較的頻繁に使われていることだ。教科書の読 みを中心に進める授業形態の中でコミュニケーション活動を行うとすれば、生徒への 指示を英語で出すことと、教科書の内容について英語で問答することが出発点にな ろう。それらが可能になれば、教科書の内容を英語で説明して導入し、教科書の内 容についてぺアで質問応答をしあう、というように様々な活動が可能になるであろう。 前者はパーマーの提唱する「オーラル・メソッド」や渡辺時夫氏が実践した「メリア・ア プローチ」、後者は金谷憲氏が現場の英語教師と協力してまとめた「和訳先渡し」で 使われ、ともに教室で実践されていることをNishino(2009)が報告している。また、教 科書の内容や文法と関連づけたタスクを中心に授業を進めるフォーカス・オン・フォー 厶も実践されている(和泉，2009参照)。CLTは欧米で考案された教え方であるから、 日本のEFL教室のようなそれと異なつた環境にそのままの形で導入することは難しい (Li，1998参照)。そのことを考慮に入れ、CLTの理念に学びつつも、日本の教育現場 で開発、改良されてきた様々なコミュニケーション活動や教授法にも目を向け、精選 し、広めることができれば、日本の高校の英語の授業で使えるコミュニカティブな授 業が定着していく可能性が高い。日本人高校教員が授業実践から作りあげてきた教 え方を定着させていくことが有用かつ現実的であろう。

\section{日本人高校教師は、自分自身の英語教師としての能力、教職課程、教員研修、教育 環境、学習経験をどのように受けとめているか。}

ここではCLTの実践に影響を与えていると考えられる要因について、英語教師とし ての能力、教師専門教育 (教職課程、教員研修)、教育環境、学習経験の順に考察す る。

教師自身の能力評価では、文法の知識を高く評価していることと、CLTの指導に関 係する能力を英語力 (聞く、読む、書く)や生徒管理能力より低く評価していることが 特徵としてあげられる。CLTの指導に自信のない教師は、授業に取り入れるのに躊踷 するだろう。しかし、自信がないので使わない、使わないから自信がもてない、この繰 り返しでは発展がない。悪循環を断ち切る手立てが必要である。

コミュニカティブな授業にする一つの方法として、和泉(2009)は次のような提案を している: 
もしこれまでに授業でタスク活動をあまり試したことがないのであれ ば、最初は月1回位ずつの割合で、タスクをとりいれるところから始め てはいかがだろうか。徐々に教材のストックをふやしていけば、タスク のレパートリーは自ずと増えてくる。現在使用している教科書に何らか の手を加えてタスク化していくことも、積極的に取り組んでいきたい。 いずれにしても、持続的な努力が大事である。(p. 225)

この提案のように、今までの授業のやり方を一遍に変える必要はなく、教科書を活 かしつつ、徐々にコミュニケーション活動をとりいれればよいのではないだろうか。同 書で和泉は、練習問題をタスクに改良する方法も示している。これも教室実践に活用 できるだろう。

また、コミュニケーション活動の工夫や授業での指導法などは、実際のやり方を 見て学ぶことが大切である。Bandaura（1977）によれば、学びは他人に見本を示して もらい追体験（vicarious experience）することで効果が上がるという。さらに教師 は、同僚や自発的に参加する研究会や勉強会などのような「実践共同体」(Wenger, 1998）の中で、仲間と話したり授業を観察したりすることから学び、自らの実践に生 かす (Canagarajah, Stevens, Nishino, \& Hoelker, 2010)。追体験のできる教員研修や、 実践共同体に参加できる時間を保証することこそ、授業改善につながるといえる。

では教師専門教育の現状はどうだろうか。まず教職課程について古家 (2008)は、 大学の英語科教育法では、主に理論的な内容が扱われていると報告した。本調査で も「第二言語習得理論の理解が深まった」という項目以外のすべての項目 (CLTの推 奨、グループワークやペアワーク、CLT教材の提供、CLT授業の観察、CLTの模擬授 業など)について、教職課程は教員研修よりも平均值が低く、実践的な指導は教職課 程の方が少なかったことを示している。また、教員研修については、約8割の回答者 はCLTが推奨されていたと回答しており、約 6 割が、第二言語習得の知識、グループ ワークやペアワーク、教材、授業観察などについて学ぶことができたと答えている。逆 にCLTを使っての模擬授業を体験した割合はやや少ない。

本調査の参加者のうち教員主催の研究会に属している割合はわずか 1 割である から、これらの回答は主に公的研修に関するものと考えてよいだろう。また、本調査 は5年計画の悉皆研修のうち、4年目の研修が終了した時期におこなわれたため、多く の回答者が悉皆研修を終えていたことになる。初任者研修、教職経験5年、10年、15 年の教員を対象にした研修では、授業のやり方に関してあまり時間を割けない現状 (Nishino, 2008)の中で、半数以上の回答者がCLTを追体験できる授業観察を経験 し、具体的な教え方 (グループワークやペアワーク、教材)も学べたと答えたことは、悉 皆研修を含む公的教員研修の成果としてある程度評価に值するだろう。ただ悉皆研 修は都道府県ごとに差があり、その内容があまり授業実践に役立たなかったという報 告がある(江利川, 2009; 新英語教育編集部, 2008)。一方、教員免許更新制度の予備 講習で、参加者がグループによる模擬授業を行い、協議しあったことが有意義であつ たという報告もある(高橋, 2008)。様々な公的教員研修の反省を踏まえ、さらに効果 的な教師専門研修が実施されることを願つてやまない。

教育環境については2つに焦点をあてた。教室環境(生徒の実態とクラスサイズ) と 社会環境(教育政策)である。 
まず教室環境については、「生徒がコミュニケーション活動を望んでいる」、「生徒 がグループワークやペアワークで使う英語を理解できる」、「1クラスの人数がコミュニ ケーション活動に適している」に、「強く賛成」または「賛成」した回答者の割合はいず れも約1割であった。特にクラスサイズが適切であることには「強く反対」または「反対」 する回答者が約6割と多かった。クラスサイズや生徒の英語力、学習スタイルなどが 授業実践に影響することは先行研究で指摘されている(Richards \& Pennington, 1998; Schulz, 2001)。本調査においても、生徒の実態やクラスサイズが実践に影響している とすれば、日本の高校でCLTが広く実践されない理由のひとつは教室環境にあると いえるだろう。

確かに生徒の学習スタイルを変えることは難しい。だからといって生徒の期待に応 えるために、教師が効果的であると信じる教え方を回避し続けるわけにはいかない。 生徒の協力を得るためには、コミュニケーション活動をする前になぜその活動をする かという論理的根拠を説明することが重要である(Brown, 2009参照)。クラスサイズの 改善については先に述べたのでここでは割愛する。

次に文部科学省の政策については、政策が英語の授業に影響していることに6割 前後が賛成している中、「まあ賛成」の回答に3〜5割が集中している。2003年より実 施された学習指導要領も、2006年春にセンター試験に導入されたリスニングテスト も、本調査の時点で授業に影響を及ぼしてはいるが、大多数の教師が顕著に感じる ほど影響力は大きくなかったようだ。Gorsuch (2000b) は入試の改革は教室環境、学 校環境を介して間接的に教師のCLT信条に影響すると示唆し、学習指導要領がシン ボル的存在で即現場の実践に結び付いていない点も指摘した。本調査の結果はこれ らのGorsuchの報告を支持するものであり、入試改革やカリキュラム改善は教室環境 に徐々に影響する中で教師の信条をも動かし、時間をかけて浸透していくと考えられ る。さらに筆者の高等学校での教職経験に基づいて付け加えるならば、現場の教師 は学習指導要領ではなく、むしろ学習指導要領に従って執筆されている検定教科書 を拠り所としている。この事実を踏まえ、学習指導要領解説は授業の手引きとなるべ く、文型例や表現例だけでなく、それらを使って「どう教えるか」という点に言及し、実 践に基づいたコミュニカティブな教え方を具体的に示すべきであろう。

最後に学習経験について、回答者は高校時代にコミュニカティブな授業をほ とんど受けていないことがわかった。学習経験が教え方に強く影響すること(Almarza, 1996; Peacock, 2001)、また、教師は学習経験を一つの指針として教え方を学び応用 すること(Watzke，2007)などを考えると、学習経験がCLT実践にブレーキをかける一 要因であることがわかる。しかし学習経験が絶対というわけではない。教師は経験を 積む中で同僚から学び、自分自身の授業から学び、生徒からも学び、新卒当時の教 え方を改良して自分なりの教え方を作りだしていく(Nishino, 2009)。だからこそ教師 の自主的研修の重要性を再確認すべきではないだろうか。

\section{結語}

本研究は、日本人高校英語教師がCLTをどのように認知し実践しているかを探る ものである。教師認知研究の枠組みに基づき、信条、授業実践、教師としての能力、 教職専門研修、教育環境、学習経験などについて、包括的に分析できる質問票を用 い、全国から無作為抽出した高校を対象に行った調査は、現行の学習指導要領実施 
以来、本研究が初めてである。質問票の回答率は $13 \%$ と低く、高校教師全員の考え を反映しているとはいえないが、回答者の多くがCLTの理念に賛成し、コミュニカティ ブな授業を行いたいと考えていること、実際には英語I・IIの授業でコミュニケーション 活動が頻繁に行われていないことがわかった。

いきなりCLTを使えと言われても、今まで蓄積した学習経験や教育経験を否定し てスイッチを切り替えることは難しい。言語教師認知は複雑な構造をもち、多様な信 条や知識が共存している。「コミュニケーションも大切だが暗記も大切」CLTTを使い たいが自信がない」「生徒が望まない教え方を無理に使いたくない」などの様々な考 えを調整しつつ、制約を克服しつつ、教師は実践を積み重ねていく。それゆえ日本に おけるコミュニカティブな英語教育改革は、従来の教科書中心の授業を否定すること なく、徐々に自分の教室で行うコミュニケーション活動を増やしていけばよいのでは ないだろうか。これは先に述べたように、メリア・アプローチ、和訳先渡し、フォーカス・ オン・フォームを取り入れた授業などの実践で広まりつつある。

Li (1998) は西欧文化の中で培われたCLTのような教え方は外国語教育において は定着しにくいと述べた。Nishino and Watanabe(2008)は、外国語としての英語教育 では、教育環境に根ざした理論と実践を打ち立てるべきであると主張した。したがっ て、教師自身がコミュニカティブな授業を開発し改良していくのが望ましい。将来的 には教師自身の知恵と実践から、日本の教室で使える「自前の」コミユニカティブ・アプ ローチを確立すべきであろう。

そのために教師が同僚や教師仲間から学べる研修の場と時間を保証し、1クラスの 生徒数を減らすことが求められている。入試改革も大切だが、教師の声に根ざした教 育環境の改善と自主的研修の保証も同じく必要であろう。また、研究者は理論的裏付 けをするだけでなく、授業改善に協力すべきである。言語教師認知研究は教師認知 をさらに深く理解することに加え、自前のコミュニカティブ・アプローチの開発を援助 する方向性が必要であろう。

\section{謝辞}

本研究は、博士論文の一部を書き直したものである。主査としてご助言くださった デヴィッド・ベグラー先生、英文要旨にコメントをくださったイートン・チャーチル先生 に感謝の意を表します。

注

1. 日本語訳は笹島・ボーグ(2009)を参考にしているが、「文脈要因」と「ビリーフ」に ついては、それぞれ「教育環境」および「信条」と表した。

2. タスク(あるいは夕スク活動)とは、相互交流するなかで課題を達成するコミュニ ケーション活動と定義する。詳しくは和泉 (2009) 参照。

3. 選抜方法の多様化、大学センター試験の改良などで大学入試問題は改善され てきているが、各大学の行う二次試験には文法や訳を問う問題が未だに多い (Kikuchi, 2006)。 
4. 47都道府県の中から 5 県を無作為に抽出し、それぞれの県 (青森、宮城、愛知、 岡山、広島)の高等学校のリストに番号をふり、乱数表を使って各県から40校選 び、質問票を10部ずつ送付した。各県の1校あたりの平均英語教員数から割り出 して、約1,090名が質問票を受け取ったと推測できる。

5. 本論文でのコミュニケーション活動は、「英語を使って表現あるいは理解する活 動」と広く定義する。すなわちインフォメーション・ギャップ(コミュニケーションを とる人々が補い合う情報を保持)のある活動とは限定しない。

6. $\mathrm{t}$ 検定を6回行っているため、有意水準を.008 $(.05 \div 6)$ とした。

7. 回答者の多くが進学校出身者であることが、コミュニケーション活動を経験しな かった一因とも考えられるが、進学校以外の高校 (主に職業高校) でコミュニケー ション活動が行われていたかどうかについて、当時の調査 (Browne \& Wada, 1998; Gorsuch, 2000a) で結論の一致をみないため断言できない。

8. 公立高校の専任教員数はクラス数によって決まるため、1クラスの生徒数が減つ ても、教員一人が受け持つ授業数が増えることはない。

西野孝子(Takako Nishino) はテンプル大学日本校大学院にて教育学博士を取得。 主な研究領域は言語教師認知研究、多読、第二言語習得への社会認知的アプローチ (Sociocognitive approach to SLA)などである。

\section{引用文献}

Almarza, G. (1996). Student foreign language teachers' growth. In D. Freeman \& J. C. Richards (Eds.), Teacher learning in language teaching (pp. 50-78). Cambridge: Cambridge University Press.

Bandaura, A. (1977). Self-efficacy: Toward a unifying theory of behavior change. Psychological Review, 84, 191-215.

Borg, S. (2003). Teacher cognition in language teaching: A review of research on what language teachers think, know, believe, and do. Language Teaching, 36, 81-109.

Borg, S. (2006). Teacher cognition and language education: Research and practice. London: Continuum.

Brown, A. V. (2009). Students' and teachers' perceptions of effective foreign language teaching: A comparison of ideals. The Modern Language Journal, 93, 46-60.

Brown, H. D. (2001). Teaching by principles: An interactive approach to language pedagogy (2nd ed.). Englewood Cliffs, NJ: Prentice Hall Regents.

Browne, C. M., \& Wada, M. (1998). Current issues in high school English teaching in Japan: An exploratory survey. Language, Culture, and Curriculum, 11, 97-112.

Burns, A. (1996). Starting all over again: From teaching adults to teaching beginners. In D. Freeman \& J. C. Richards (Eds.), Teacher learning in language teaching (pp. 154-177). Cambridge: Cambridge University Press. 
Canagarajah, S., Stevens, V., Nishino, T., \& Hoelker, J. (2010). EFLIS Academic Session 2009. Global and Local Perspectives: Evolving Communities of Practice in EFL. A Periodic Newsletter for TESOL Members, 9(1). Retrieved from http://www.tesol. org//s_tesol/sec_issue.asp?nid=2994\&iid=13069\&sid=1

Clark, C. M., \& Peterson, P. (1986). Teachers' thought processes. In M. C. Wittrock (Ed.), Handbook of research on teaching (3rd ed.) (pp. 255-296). New York: Macmillan.

Crookes, G. (1997). What influences what and how second and foreign language teachers teach? The Modern Language Journal, 81, 67-79.

Crookes, G., \& Arakaki, L. (1999). Teaching idea sources and work conditions in an ESL program. TESOL Journal, 8, 15-19.

Doughty, C., \& Pica, T. (1986). "Information gap" tasks: Do they facilitate second language acquisition? TESOL Quarterly, 20, 305-325.

江利川春雄. (2009).『英語教育のポリティクス』. 東京:三友社.

Fang, Z. (1996). A review of research on teacher beliefs and practices. Educational Research, 38, 47-64.

古家貴雄. (2008).「英語教育における言語教師認知研究の意義」。第47回JACET全 国大会発表資料.

Gorsuch, G. (1998). Yakudoku EFL instruction in two Japanese high school classrooms: An exploratory study. JALT Journal, 20, 6-32.

Gorsuch, G. (2000a). Exploring the relationship between educational policy and instruction in Japanese high school EFL classrooms (Doctoral dissertation). Retrieved from http://proquest.umi.com/pqdweb?did=729764301\&sid=1\&Fmt= $2 \&$ clientId $=18902 \& \mathrm{RQT}=309 \& \mathrm{VName}=\mathrm{PQD}$

Gorsuch, G. (2000b). EFL educational policies and education cultures: Influences on teachers' approval of communicative activities. TESOL Quarterly, 34, 675-710.

和泉伸一. (2009).『「フォーカス・オン・フォーム」を取り入れた新しい英語教育』. 東京: 大修館.

萩原剛・太田裕之・藤井聡. (2006).「アンケート調査回収率に関する実験研究: MM 参加率の効果的向上方策についての基礎的検討」.『土木計画額研究·論文集』, 23, 117-123.

弘山貞夫. (2009).「英語の授業は英語だけで?」『新英語教育』, 479, 13-15.

Holt-Reynolds, D. (1992). Personal history-based beliefs as relevant prior knowledge in course work. American Educational Research Journal, 29, 325-349.

Kikuchi, K. (2006). Revising English entrance examinations at Japanese universities after a decade. JALT Journal, 28, 77-96. 
Kikuchi, K., \& Browne, C. (2009). English educational policy for high schools in Japan: Ideals vs. reality. RELC Journal, 40, 172-191.

Li, D. (1998). "It's always more difficult than you plan and imagine": Teachers' perceived difficulties in introducing the communicative approach in South Korea. TESOL Quarterly, 32, 677-703.

文部省. (1989).『高等学校学習指導要領』. 東京: 大蔵省印刷局.

文部省. (1999).『高等学校学習指導要領』. 東京:国立印刷局.

文部科学省. (2003).「英語が使える日本人」育成のための行動計画. Retrieved from http://www.mext.go.jp/b_menu/shingi/chukyo/chukyo4/007/gijiroku/03032401/009.pdf

文部科学省. (2009)、『高等学校学習指導要領』. 東京:東山書房.

Nishino, T. (2008). Japanese secondary school teachers' beliefs and practices regarding communicative language teaching: An exploratory study. JALT Journal, 30, 27-50.

Nishino, T. (2009). Communicative language teaching in Japanese high schools: Teachers' beliefs and classroom practices (Doctoral dissertation). Retrieved from ProQuest Dissertations and Theses Database. (UMI No. 3371994).

Nishino, T. \& Watanabe, M. (2008). Communication-oriented policies versus classroom realities in Japan. TESOL Quarterly, 42, 133-138.

Nunan, D. (2003). The impact of English as a global language on educational policies and practices in the Asia-Pacific region. TESOL Quarterly, 37, 589-613.

OECD. (2010). Education at a glance 2010: OECD indicators. Retrieved from http:// www.oecd.org/document/52/0,3343,en_2649_39263238_45897844_1_1_1_1, 00.html

Pajares, M. F. (1992). Teachers' beliefs and educational research: Cleaning up a messy construct. Review of Educational Research, 62, 307-332.

Peacock, M. (2001). Pre-service ESL teachers' beliefs about second language learning: A longitudinal study. System, 29, 177-195.

Phipps, S., \& Borg, S. (2009). Exploring tensions between teachers' grammar teaching beliefs and practices. System, 37, 380-390.

Richards, J. C., \& Pennington, M. (1998). The first year of teaching. In J. C. Richards (Ed.), Beyond training (pp. 173-200). Cambridge: Cambridge University Press.

Richards, J. C., \& Rodgers, T. S. (2001). Approaches and methods in language teaching. Cambridge: Cambridge University Press.

Sakui, K. (2004). Wearing two pairs of shoes: Language teaching in Japan. ELT Journal, 58, 155-163. 
笹島茂・ボーグ, S. (2009).『言語教師認知の研究』. 東京:開拓社.

Schulz, R. A. (2001). Cultural differences in student and teacher perceptions concerning the role of grammar instruction and corrective feedback: USA - Colombia. The Modern Language Journal, 85, 244-258.

新英語教育編集部. (2008).「英語教員指導力向上研修についてのアンケート」,『新英 語教育』, 463, 10-12.

Smylie, M. A. (1988). The enhancement function of staff development: Organizational and psychological antecedents to individual teacher change. American Educational Research Journal, 25, 1-30.

高橋一幸. (2008).「教師を動機づける講習を志向して:教員免許更新制の予備講習 報告＼cjkstart神奈川大学」.『英語教育』. 57, 17-19.

卯城祐司.(2003).「研修プログラムのモデルケース」『英語教育』, 52, 14-17.

Watzke, J. L. (2007). Foreign language pedagogical knowledge: Toward a developmental theory of beginning teacher practices. The Modern Language Journal, 91, 63-82.

Wenger, E. (1998). Communities of practice: Learning, meaning, and identity. New York: Cambridge University Press.

Woods, D. (1996). Teacher cognition in language teaching. Cambridge: Cambridge University Press. 
